\title{
Lorenzo-Modia, María Jesús and Carmen María Fernández Rodríguez Eds. 2017. Frances Burney. El ridículo ingenio. Un dia de mucho apuro. Sevilla: Arcibel Editores. 293 pages. \\ Ángeles Tomé Rosales (angelestome@uvigo.es) \\ Centro de Linguas (Fundación Universidade de Vigo)
}

This noteworthy volume is divided into three main sections: the introduction, the translation of The Witlings and the translation of $A$ Busy Day. Both comedies by Frances Burney have been translated into Spanish by Carmen María Fernández Rodríguez. Before plunging into the comedies, Spanish-speaking readers have the possibility to learn about Burney and her work in a comprehensive introductory section written by María Jesús Lorenzo-Modia and the abovementioned Carmen María Fernández Rodríguez. In the first paragraph of the introduction, the editors claim that their main goal consists of offering Spanish-speaking readers the first translations into Spanish of these two comedies written by Burney in the eighteenth century. Besides, they point out that the choice of these two comedies was not carried out randomly: not only are the two of them meaningful within Burney's work, but they also highlight both her satire of social conventions and her interest in standing out as a playwright.

After this first revealing paragraph, the introduction contains three different main sections: the first deals with Burney's biography, the second revolves around Burney's non-theatrical and theatrical work and the last abridges the outgrowing number of works that the editors resorted to. Regarding this introduction, it is remarkable that all of the English terms/paragraphs that the editors have to mention/quote have been translated into Spanish in footnotes. After speaking about Burney's parents, who contributed to her successful career as a writer, the editors summarise Burney's life by making a connection between her most important works and the different periods of her life.

The second section of this introduction, which focuses on Burney's work, is divided into two main sections: Burney's nontheatrical and theatrical production. Regarding the section which deals with her non-theatrical production, it is worth noting that, apart from mentioning the different genres that the author worked on, the 
editors pay special attention to the reception of Burney's work among literary critics not only during her life but also after her death. It is necessary to congratulate the editors on the impressive section dealing with the reviews of Burney's work published in the eighteenth century. Thanks to the research carried out by the editors, it is possible to know what contemporary critics wrote about Burney's different novels. Moreover, apart from putting all the contemporary criticism together, the editors analyse the reasons why some negative reviews of Burney's work were published at the time and make reference to reviews which show opposite views about Burney's nondramatic production.

About the reception of Burney's work in the 1900s, the editors mention all the authors who were interested in Burney throughout the twentieth century. However, they make special reference to the two biographies which were published in the second half of the century and which became a valuable source for all the scholars doing research on Burney from 1980 up to the twenty-first century. This period is also important because it was the time when Burney started to be considered a feminist author. The editors do not stick to the interest in Burney's work, but they also deal with the research carried out on works by some of Burney's relatives, such as her stepsister, her niece or her brother. To finish this section, the editors move on to the literary works which have been influenced by Burney's work. Among them, it is worth noting such remarkable literary works as Vanity Fair, Emmeline or Pride and Prejudice. Finally, they make a brief reference to the research that scholars have carried out on Burney's work in Spain.

Regarding her dramatic production, the editors argue that, although Burney's comedies and tragedies are the sources of her narrative work, they have neither been frequently quoted nor translated into other languages. There are few scholars who have done research on Burney's plays despite having started to be analysed from a feminist perspective. The editors make reference to the topic, the characters, and the plots of Burney's plays. This section includes two subsections that focus on the two comedies translated into Spanish and included in the volume, namely El ridículo ingenio and Un día de mucho apuro. 
The first subsection deals with El ridiculo ingenio, which is a typically English comedy from the time, as it is split up into five acts which contain several scenes and different settings. Moreover, the characters belong to different social ranks (upper class, middle class, and working class). As the author includes upper-class and working women, the female world becomes remarkable within the comedy. As the editors claim, the plot is about the relationship between Cecilia and Beaufort, Lady Smatter's nephew. Determined to avoid Cecilia and Beaufort's marriage, Lady Smatter attempts to send Cecilia to the country and, thus, make her nephew forget her. Nevertheless, thanks to Censor, Beaufort's friend, eventually Lady Smatter allows Cecilia and Beaufort to marry. On the one hand, the comedy is packed with references to the most important classical and contemporary writers. The playwright focuses on the social differences between rich women and those women who lack money, who frequently resort to prostitution to earn a living.

As was said above, Un dia de mucho apuro is the other comedy included in this volume. Both pieces are connected because they both deal with the superficial and omit the daily problems that eighteenthcentury people had to face. Taking all the comedies written by Burney into account, the editors reckon that Un dia de mucho apuro is by far the most entertaining and the closest to Evelina and Jane Austen's novels. Moreover, the play is full of puns similar to the ones in Shakespeare's As You Like It or Twelfth Night. Before dealing with the plot, the editors include information about the time when the play was performed and the reviews about it published, which might help readers to ascertain how significant this play was. In Un día de mucho apuro, Burney criticises affected behaviour on the part of those who became rich during the eighteenth century due to the Industrial Revolution and the expansion of the British Empire. On the contrary, the main features of the upper class are selfishness and hypocrisy. Burney's goal might be to show that bad manners cannot be identified with only one part of society.

Finally, the editors include a third section containing all the works which were necessary to write the comprehensive introduction to this volume. The volumes included in this last section of the introduction can be classified into three main groups: Burney's works, books on the history of English Literature, and articles which analyse different 
aspects of Burney's literary production. As it could be inferred from the thoroughness of the introductory section, the amount of volumes to which the editors resorted makes the introductory section a useful instrument for both researchers who would like to delve deeper into Burney's works and Spanish-speaking people who feel attracted by eighteenth-century female authors.

After the introduction, readers will find the translation of both comedies into Spanish. As the translator explains, the names and some titles have been kept in English. As names are difficult to translate properly, the translator's decision is the best she could haven taken. Nevertheless, for Spanish-speaking readers, it might be useful to know the meaning of the characters' names in order to better understand their functions within the plays. Moreover, regarding $E l$ ridiculo ingenio, the translator has tried to make most of the verses rhyme, as in the original text, an effort that the readers will definitely appreciate. She has also used non-standard Spanish to translate those parts in which slang terms are used, which may help readers distinguish educated from uneducated characters, as this distinction might be meaningful for the plot.

After having read the volume, it is necessary to congratulate the editors and translator for allowing Spanish-speaking readers to have access to Burney's work. It is true that Burney is not a well-known author in Spain and, although there might not be many people interested in her work, it can be inferred that one of the reasons may be the unavailability of a Spanish version of Burney's work. Apart from this, I would also like to highlight the comprehensive introduction which foregoes the translation. Not only does it provide readers with an extensive account of Burney's literary production, but it also makes reference to authors who have done research on Burney's work and their most relevant contributions. Therefore, the introduction could also be used as a point of departure to start studying Burney's work. On the negative side, we could mention some minor typos throughout the volume, such as the repetition of prepositions ("aportación de de Fanny Burney," p. 26), multiple spaces between words ("Barbara Darby aprecia desde el feminismo," p. 30), or misspelt words ("ambas están obsesionadas son satisfacer su ego," p. 36). These are definitely minor errors which do not undermine the quality of the volume at all. 